ISSN: $\underline{2656-7466}$

\title{
PERSEPSI MAHASISWA \\ JURUSAN PENDIDIKAN AGAMA HINDU TERHADAP PENGGUNAAN \\ TEKNOLOGI INFORMASI DAN KOMUNIKASI \\ DALAM PEMBELAJARAN \\ Oleh
}

\section{Gede Harja Subrata}

\begin{abstract}
ABSTRAK
\end{abstract}
Penelitian ini bertujuan untuk melihat bagaimana persepsi mahasiswa Jurusan Pendidikan Agama Hindu terhadap penggunaan Teknologi Informasi dan Komunikasi dalam pembelajaran. Subjek dari penelitian ini adalah seluruh mahasiswa jurusan pendidikan agama hindi di STKIP Agama Hindu yang pembelajarannya menggunakan TIK. Data dalam penelitian ini dikumpulkan melalui kuesioner,interviu dan dokumen, dan dianalisis secara deskriptif-kualitatif. Hasil penelitian menunjukkan bahwa secara umum persepsi mahasiswa terhadap penggunaan TIK dalam pembelajaran adalah positif. Hal ini dapat dilihat bahwa 87,3\% mahasiswa mengatakan senang dengan pembelajaran dengan TIK yang dilihat dari prosentase persepsi mahasiswa ditinjau dari kebermanfaatannya terhadap diri mereka secara pribadi, proses pembelajaran dan hasil belajar. Persepsi positif mahasiswa terhadap penggunaan TIK dalam pembelajaran dilihat dari kebermanfaatannya kepada mahasiswa secara pribadi adalah : menambah pengetahuan dan wawasan mahasiswa tentang teknologi, dengan kata lain tidak gaptek (96\%), dengan menggunakan blog, mahasiswa bisa berkomunikasi dan berbagi ilmu pengetahuan dengan lebih banyak orang (78\%), dengan menggunakan TIK mahasiswa dapat download banyak hal, sehingga wawasan yang dimiliki tidak hanya sebatas informasi yang diberikan poleh dosen dan teman (80\%), dengan informasi yang lebih banyak, mahasiswa merasa lebih bisa berkreasi (kreatif) (67\%). Persepsi positif mahasiswa terhadap penggunaan TIK dalam pembelajaran dilihat dari kebermanfaatannya terhadap proses pembelajaran adalah: pembelajaran menjadi tidak membosankan karena mahasiswa tidak hanya mendengarkan ceramah dari dosen (100\%), sangat mempermudah pembelajaran karena visualisasi, gambar dan film yang dipergunakan dalam presentasi lebih cepat membuat mahasiswa mengerti tentang topic yang diajarkan (99\%), penggunaan TIK dapat mempermudah dan mempercepat mencari sumber-sumber referensi untuk tugas (80\%), Penggunaan TIK dalam pembelajaran membuat suasana belajar lebih menyenangkan (72\%), dsbnya. 
Hasil belajar yang diperoleh dari pemanfaatan TIK dalam pembelajaran adalah : 77,7 \% untuk mata kuliah keterampilan keagamaan. Sedangkan untuk mata kuliah kependidikan sebesar $83 \%$.

Kata kunci : persepsi, teknologi informasi dan komunikasi, trend, download

\begin{abstract}
The changing paradigm in education from teacher cemtered to student centered, and the development of technology, caused great changes in the process of teaching and learning at the Religion Department at STKIP Agama Hindu. The use of technology then becoming trends in teaching. However, none of the staff do research on the students' perception toward the use of Information Communication Technology (ICT) in teaching. For it is important to know whether the use of ICT giving a positive effect to the students themselves and to the process of teaching in general, this research then was then to meet that purpose. The subject of this research are all the students at the Religion Department at STKIP Agama Hindu, whose subject was taught by using ICT. Datas of this research were collected by the used of questionnaire, interviu guide, and documents. Datas that has been collected then were analysed descriptively and qualitatively. The result of the research showed that in general the students' perception toward the used of ICT in teaching was positive. This can be proven by the percentage of the students who liked the teaching learning using ICT which is $87,3 \%$. It is also supported by the result of the quesionaire which said that the used of ICT giving many benefit to students, the teaching learning process and the students' final exam. In relation to personal benefits : $96 \%$ of the students said that ICT can broadened their knowledge and skill in using technology, 78\% said that blog is a good means to communicate and share the knowledge, $80 \%$ said that the used of ICT could enrich their knowledge, because they can download the information from the internet to add the information that they got from the lecturer, $67 \%$ said that they are becoming more creative after using ICT in learning something. In relation to the significance of ICT for the teaching process, 100\% said that ICT could avoid borthersome, $99 \%$ said that the used of ICT especially the used of visualization could ease them to understand the subject, $80 \%$ said that ICT could help them in finding more references, $72 \%$ said that ICT could make an interesting learning atmosphere. The significance of ICT toward the result of the students final exam, can be seen from the
\end{abstract}


result that ICT can $77,7 \%$ improve their knowledge in the course related to Hindhus religion and $83 \%$ could improve their result in pedagogical courses.

Key Word : students' perception, Information Communication Technology (ICT), trend, download

\section{PENDAHULUAN}

Pergeseran paradigma dalam pendidikan yang semula terpusat menjadi desentralistis membawa konsekuensi dalam pengelolaan pendidikan baik di sekolah maupun di Perguruan Tinggi. Desentralisasi memberikan otonomi yang seluas-luasnya kepada sekolah dan Perguruan Tinggi untuk mengelola institusinya baik dalam pengembangan kurikulum maupun berinovasi dalam menggunakan model dan strategi pembelajaran.Konsekuensi yang harus ditanggung oleh sekolah atau perguruan Tinggi adalah restrukturisasi dalam pengelolaan institusi (capacity building), profesionalisme guru, penyiapan infrastruktur, kesiapan mahasiswa dalam proses belajar dan iklim akademik institusi.

Sejalan dengan perkembangan teknologi informasi dan pembelajaran berbasis teknologi informasi yang sangat pesat, lembaga pendidikan dalam hal ini perguruan tinggi telah melakukan berbagai upaya untuk mampu mengikuti irama perubahan paradigma pendidikan. Khusunya di Jurusan pendidikan agama hindu

Ada beberapa tujuan pembelajaran dengan menggunakan Teknologi Informasi, UNESCO (2002) menyatakan bahwa penggunaan TIK ke dalam proses pembelajaran memiliki tiga tujuan utama: 1) untuk membangun "knowledge-based society habits" seperti kemampuan memecahkan masalah (problem solving), kemampuan berkomunikasi, kemampuan mencari, mengoleh/mengelola informasi, mengubahnya menjadi pengetahuan baru dan mengkomunikasikannya kepada oranglain; 2) untuk mengembangkan keterampilan menggunakan TIK (ICT literacy); dan 3) untuk meningkatkan efektifitas dan efisiensi proses pembelajaran.

Oleh karena itu sebenarnya banyak keuntungan yang diberikan oleh pemanfaatan TIK dalam pembelajaran, seperti apa yang disampaikan oleh Jonassen (1995), dikutip oleh Norton et al (2001)) TIK memainkan peran yang sangat luar biasa untuk mendukung terjadinya proses belajar yang: (1) Active; memungkinkan mahasiswa dapat terlibat aktif 
oleh adanya proses belajar yang menarik dan bermakna; (2) Constructive; memungkinkan mahasiswa dapat menggabungkan ide-ide baru kedalam pengetahuan yang telah dimiliki sebelumnya untuk memahami makna atau keinginan tahuan dan keraguan yang selama ini ada dalam benaknya; (3) Collaborative; memungkinkan mahasiswa dalam suatu kelompok atau komunitas yang saling bekerjasama, berbagi ide, saran atau pengalaman, menasehati dan memberi masukan untuk sesama anggota kelompoknya; (4) Intentional; memungkinkan mahasiswa dapat secara aktif dan antusias berusaha untuk mencapai tujuan yang diinginkan;(5) Conversational; memungkinkan proses belajar secara inherent merupakan suatu proses sosial dan dialogis dimana siswa memperoleh keuntungan dari proses komunikasi tersebut baik di dalam maupun luar sekolah; (6) Contextualized; memungkinkan situasi belajar diarahkan pada proses belajar yang bermakna (real-world) melalui pendekatan "problem-based atau case-based learning", (7) Reflective; memungkinkan mahasiswa dapat menyadari apa yang telah ia pelajari serta merenungkan apa yang telah dipelajarinya sebagai bagian dari proses belajar itu sendiri.

Disamping keuntungan di atas, pemanfaatan TIK dalam pembelajaran dapat membangun budaya belajar yang positif seperti yang disampaiakan oleh Bates (2005) dalam journal of e-learning volume 5 tahun 2005 yaitu : mahasiswa dituntut secara mandiri dalam belajar dengan berbagai pendekatan yang sesuai agar mereka mampu mengarahkan, memotivasi, mengatur dirinya sendiri dalam pembelajaran. Kedua, dosen harus mampu mengembangkan pengetahuan dan ketrampilan mahasiswa, memfasilitasi mahasiswa dalam pembelajaran, serta memahami hal-hal yang dibutuhkan oleh mahasiswa dalam pembelajaran. Ketiga tersedianya infrastruktur yang memadai.

Berdasarkan keuntungan di atas, dapat dibayangkan apa yang terjadi dengan kualitas proses dan hasil pendidikan di jurusan pendidikan bahasa Inggris. Secara ideal bila semua dosen menggunakan dan memanfaatkan e-learning dalam pembelajaran, jarak bukan lagi menjadi masalah dalam pembelajaran, kehadiran guru di dalam kelas tidak lagi menjadi keharusan, kebosanan siswa sebagai dampak penggunaan metode ceramah dosen tidak lagi ada, serta mahasiswa tidak lagi tergantung dengan waktu untuk mengikuti perkuliahan. Dampak dari semua ini diharapkan kualitas pembelajaran di jurusan pendidikan agama hindu menjadi lebih berkualitas. Sehingga apa yang disampaikan oleh Hoser seperti kalimat di bawah ini dapat tercapai : 
ISSN: $\underline{2656-7466}$

"In a global economy, it is education, not location, that determines the standard of living."

-Albert Hoser, CEO of Siemens- http://www.wtvi.com/teks/tia

Akan tetapi selain keuntungan yang telah disebutkan di atas, dosen dituntut untuk memiliki beberapa kompetensi seperti kompeten dalam membuat desain instruksional (instructional design) sesuai dengan kaedah-kaedah paedagogis yang dituangkan dalam rencana pembelajaran serta kompeten dalam memanfaatkan internet sebagai sumber pembelajaran.

Berdasarkan keuntungan yang diberikan serta tuntutan yang diperlukan untuk melaksanakan pembelajaran dengan memanfaatkan TIK, perlu dilihat apakah pembelajaran di jurusan pendidikan agama hindu telah mampu memenuhi standar kualitas baik kualitas proses maupun hasil belajar. Disamping itu apakah mahasiswa memang sudah merasakan keuntungan seperti yang disampaikan di atas.

Untuk itulah penelitian ini ingin mengetahui ' Bagaimana Persepsi Mahasiswa Jurusan Pendidikan Agama Hindu terhadap Penggunaan Teknologi Informasi dan Komunikasi Dalam Pembelajaran’

\section{METODE}

Penelitian ini merupakan jenis penelitian kualitatif survey yang bertujuan untuk mengexplorasi atau memperoleh gambaran tentang persepsi mahasiswa jurusan pendidikan agama hindu terhadap pemanfaatan TIK dalam pembelajaran. Menurut Susan Stainback (1998), desain penelitian survey pada umumnya singkat dan bersifat sementara.

Subjek dari penelitian ini adalah seluruh mahasiswa jurusan pendidikan agama hindu STKIP Agama Hindu Singaraja yang pembelajarannya menggunakan TIK Ada tiga instrumen yang digunakan untuk menilai proses belajar dan hasil belajar yaitu kuesioner, interview guide, dan dokumen. Kuesioner digunakan untuk mengetahui persepsi mahasiswa terhadap pemanfaatan TIK dalam pembelajaran. Melalui kuesioner dapat diperoleh apakah TIK mampu memenuhi tujuan pembelajaran yang telah didisain oleh dosen, serta mampu meningkatkan hasil belajar mereka. Disamping manfaaat yang diperoleh mahasiswa, melalui kuesioner dapat dicari hambatan-hambatan yang ditemukan oleh mahasiswa bila dosen menggunakan teknologi dalam pembelajaran. Interview Guide digunakan untuk melakukan triangulasi terhadap jawaban yang diberikan oleh mahasiswa dalam kuesioner. Interview guide ini dipergunakan sebagai tuntunan dalam melakukan 
Focus Group Discussion. Dokumen dalam penelitian ini adalah dokumen hasil belajar mata kuliah yang diambil oleh mahasiswa yang menggunakan TIK dalam pembelajaran.

Data di atas dianalisis secara deskriptif kualitatif.

\section{HASIL}

Secara umum hasil penelitian di atas menunjukkan bahwa persepsi mahasiswa terhadap pembelajaran dengan menggunakan TIK dilihat dari 2 hal yaitu dari (1) Persepsi umum mahasiswa tentang pemanfaatan TIK dalam pembelajaran, dan (2) Hasil belajar Mata Kuliah yang menggunakan TIK dalam pembelajaran.

\section{A. Persepsi Mahasiswa Secara Umum tentang Penggunaan TIK dalam pembelajaran.}

Sehubungan dengan persepsi mahasiswa terhadap penggunaan TIK, dari 63 mahasiswa, 55 orang mengatakan senang bila dosen menggunakan TIK dalam pembelajaran, 6 orang mengatakan tidak senang dan 2 orang abstain. Ada beberapa alasan yang menyebabkan 87,3 \% mahasiswa jurusan pendidikan agama hindu yang mengambil mata kuliah dengan menggunakan TIK dalam pembelajaran merasa senang seperti :

1. Penggunaan TIK dalam pembelajaran dapat menambah pengetahuan dan wawasan mahasiswa tentang teknologi, dengan kata lain tidak gaptek.

2. Pembelajaran menjadi tidak membosankan karena mahasiswa tidak hanya mendengarkan ceramah dosen.

3. Sangat mempermudah pembelajaran karena visualisasi, gambar dan film yang dipergunakan dalam presentasi lebih cepat membuat mahasiswa mengerti tentang topik yang diajarkan.

4. Dengan menggunakan blog, mahasiswa bisa berkomunikasi dan berbagi ilmu pengetahuan dengan lebih banyak orang.

5. Dengan menggunakan TIK mahasiswa dapat download banyak hal, sehingga wawasan yang dimiliki tidak hanya sebatas informasi yang diberikan poleh dosen dan teman.

6. Dengan informasi yang lebih banyak, mahasiswa merasa lebih bisa berkreasi (kreatif).

7. Penggunaan TIK dapat mempermudah dan mempercepat mencari sumber- 
sumber referensi untuk tugas.

8. Penggunaan friendster dapat membuat banyak teman.

9. Penggunaan TIK dalam pembelajaran membuat suasana belajar lebih menyenangkan .

10. Mata kuliah yang pembelajarannya menggunakan TIK terasa lebih menarik.

11. TIK dapat membuat mahasiswa mencaritau tentang program-program baru.

12. Informasi yang diperoleh dari penggunaan TIK lebih lengkap dan banyak.

13. Penggunaan TIK dalam pembelajaran lebih memotivasi siswa untuk belajar

14. Belajar dengan menggunakan TIK terasa lebih keren.

15. Dari internet mahasiswa dapat memperoleh text-text otentik baik audio maupun tertulis.

16. Penggunaan multiply dalam pembelajaran writing dapat meningkatkan kemampuan menulis mahasiswa.

17. Topik-topik yang sama dapat dipresentasikan secara lebih beragam melalui penggunaan TIK.

18. Punya blog pribadi merupakan kebanggaan tersendiri bagi mahasiswa

19. Penggunaan TIK dalam pembelajaran, mengharuskan mahasiswa untuk lebih sering ke internet sehingga dapat menggunakan waktu lebih baik ketimbang main dengan tidak karuan. Di internet bisa belajar sambil bermain

Di samping kesenangan di atas, ada beberapa mahasiswa 0,9\% mahasiswa yang mengatakan bahwa pembelajaran dengan menggunakan TIK tidaak menyenangkan dengan alasan sebagai berikut :

1. Penggunaan TIK menghabiskan lebih banyak biaya.

2. Menyebabkan frustrasi ketika komputer dapat virus dari internet.

3. Membingungkan jika tidak mengerti cara menggunakannya.

4. Sangat membosankan jika datang ke internet yang loadingnya lambat.

5. Banyak menghabiskan waktu dan tenaga.

6. Peralatan yang ada di lembaga tidak memenuhi kebutuhan mahasiswa.

7. Menyebabkan sakit mata.

8. Pembelajaran dengan TIK mempersulit mahasiswa.

9. TIK membuat perkembangan yang sangat pesat, dan itu sangat mengkhawatirkan.

10. Pembelajaran dengan TIK terlalu praktis dan membuat mahasiswa malas untuk pergi ke perpustakaan. 
11. Mahasiswa bingung dangan system penilaian ynag diberikan dosen melalui tugas online.

12. Bila dosen sudah menerapkan pembelajaran dengan TIK, sangat diharapkan bila kampus menyediakan internet gratis.

13. Pembelajaran dengan TIK menyebabkan kurang bisanya bersosialisasi dengan dosen .

14. Kelabakan menyetor tugas apabila warnet penuh.

Hasil penelitian juga menunjukkan bahwa program yang paling disenangi oleh mahasiswa adalah blog dan atau multiply, yaitu sebanyak 61,6 \% dan google browsing sebanyak 27,4\%. Blog adalah program buku harian yang ditayangkan secara online. Dengan menggunakan blog mahasiswa bisa memberi komentar kepada informasi yang ditulis temannya, demikian juga menulis komentar, saran terhadap kasus yang diberikan oleh dosen. Multiply adalah salah satu penyedia layanan blog yang mengijinkan penggunanya meng upload lagu,video, dan file multimedia lainnya. Google browsing adalah pencarian segala jenis informasi melalui situs google. Hasil interviu dengan mahasiswa ditemukan beberapa alasan mengapa hanya $27 \%$ mahasiswa menyenangi google, yaitu karena tidak dapat dipergunakan untuk berkomunikasi. Lain halnya dengan blog dan multiply yang dipergunakan oleh mahasiswa untuk berkomunikasi dengan dosen dan antar mahasiswa.

Selain informasi di atas, untuk mengetahui persepsi mahasiswa terhadap penggunaan TIK dalam pembelajaran juga ditelusuri dengan menanyakan kepada mereka metode pembelajaran apa yang paling mereka senangi. Hasil penelitian tentang metode pembelajaran yang paling disenangi dapat dilihat pada tabel 1. berikut :

Tabel 1.

Persepsi Mahasiswa terhadap Metode Pembelajaran di Jurusan Pendidikan Bahasa Inggris

\begin{tabular}{|r|l|r|r|r|r|r|r|}
\hline No & \multicolumn{1}{|c|}{$\begin{array}{c}\text { Metode / } \\
\text { teknik } \\
\text { Pembelajaran }\end{array}$} & $\begin{array}{l}\text { Sangat } \\
\text { Suka }\end{array}$ & Suka & $\begin{array}{l}\text { Kurang } \\
\text { Suka }\end{array}$ & $\begin{array}{l}\text { Tidak } \\
\text { Suka }\end{array}$ & $\begin{array}{l}\text { Sangat } \\
\text { Tidak } \\
\text { Suka }\end{array}$ & Jml \\
\hline 1 & $\begin{array}{l}\text { Belajar dengan } \\
\text { menggunakan metode } \\
\text { lama (ceramah) }\end{array}$ & 0 & 2 & 11 & 19 & 28 & 60 \\
\hline 2 & $\begin{array}{l}\text { Belajar dengan } \\
\text { menggunakan TIK }\end{array}$ & 15 & 21 & 12 & 8 & 4 & 60 \\
\hline
\end{tabular}


ISSN: $\underline{2656-7466}$

\begin{tabular}{|r|l|r|l|r|r|r|r|}
\hline 3 & $\begin{array}{l}\text { Belajar dengan } \\
\text { menggunakan } \\
\text { observasi langsung } \\
\text { (di lapangan) }\end{array}$ & 19 & 15 & 17 & 9 & 0 & 60 \\
\hline 4 & $\begin{array}{l}\text { Belajar dengan } \\
\text { menggunakan } \\
\text { gabungan ceramah } \\
\text { dan TIK }\end{array}$ & 129 & 30 & 14 & 3 & 2 & 60 \\
\hline 5 & $\begin{array}{l}\text { Belajar } \\
\text { denganmenggunakan } \\
\text { gabungan TIK dan } \\
\text { observasi }\end{array}$ & 35 & 13 & 10 & 2 & 1 & 60 \\
\hline 6 & $\begin{array}{l}\text { Belajar dengan } \\
\text { menggunakan } \\
\text { gabungan TIK, } \\
\text { ceramah, dan } \\
\text { observasi }\end{array}$ & & & & 60 & \\
\hline
\end{tabular}

Tabel di atas menunjukkan bahwa metode pembelajaran yang paling disenangi adalah gabungan antara penggunaan TIK, ceramah dan observasi langsung. Metode yang paling tidak disenangi oleh mahasiswa adalah metode ceramah. Dari hasil penelitian tersebut dapat dilihat bahwa penggunaan TIK secara penuh, tidak terlalu disenangi oleh mahasiswa.

Sehubungan dengan efisiensi dan efektifitas penggunaan TIK dalam pembelajaran, persepsi mahasiswa adalah sebagai berikut :

1. Menghabiskan banyak uang dan waktu.

2. Sangat bagus, perlu diperhatikan.

3. Menghabiskan banyak biaya.

4. Alangkah baiknya bila ada internet gratis bagi mahasiswa.

5. Kampus diharapkan menyediakan fasilitas.

6. Sangat boros.

7. Sangat membantu mahasiswa.

8. Kerusakan koneksi internet dan majhalnya biaya internet.

9. Keterbatasan sarana internet di singaraja.

10. Mahasiswa mengharapkan adanya kerjasama antara pengusaha internet dengan kampus sehingga kualitas pembelajaran dengan TIK bisa ditingkatkan.

11. Cukup efektif untuk menambah pengetahuan.

12. Pengeluaran banyak tetapi mendapat ilmu yang banyak.

13. Mahasiswa belum sepenuhnya menguasai TIK.

14. Mahasiswa selayaknya mendapat layanan internet murah. 
15. TIK memberikan pengalaman yang berbeda, sehingga pembelajaran tidak membosankan.

16. TIK tidak sesuai apabila diberikan dalam jangka waktu yang lama. Karna hanya menguras kantong.

\section{B. Hasil belajar Mata Kuliah yang menggunakan TIK dalam pembelajaran}

Dari kartu hasil studi mahasiswa diperoleh kisaran nilai yang diperoleh mahasiswa pada mata kuliah yang pembelajarannya menggunakan TIK sperti dalam tabel 2 berikut :

Tabel 2.

Rangkuman Kisaran Nilai Mata Kuliah Yang Menggunakan TIK

\begin{tabular}{|l|l|l|l|l|l|r|r|l|}
\hline \multirow{2}{*}{ No } & \multicolumn{1}{|c|}{ Mata Kuliah } & \multicolumn{6}{|c|}{ Kisaran Nilai } & \multirow{2}{*}{ Jml } \\
\cline { 3 - 9 } & & $\mathbf{A}$ & $\mathbf{\%}$ & $\mathbf{B}$ & $\mathbf{\%}$ & $\mathbf{C}$ & $\mathbf{D}$ & \\
\hline 1 & Sejarah agama hindu & 12 & 24 & 36 & 72 & 2 & 0 & 50 \\
\hline 2 & $\begin{array}{l}\text { Theory Penyuluhan } \\
\text { gama }\end{array}$ & 14 & 66 & 7 & 33 & 0 & 0 & 21 \\
\hline 3 & Etika Hindu & 1 & 6,2 & 15 & 93,7 & 0 & 0 & 16 \\
\hline 4. & Wiracarita & 2 & 3,5 & 51 & 89,4 & 4 & 0 & 57 \\
\hline 5 & Media Pendidikan & 5 & 8,6 & 53 & 91,3 & 0 & 0 & 58 \\
\hline 6. & $\begin{array}{l}\text { Profesi } \\
\text { Kependidikan }\end{array}$ & 6 & 13,6 & 33 & 75 & 2 & 0 & 44 \\
\hline 7 & $\begin{array}{l}\text { Pengembangan } \\
\text { Kurikulum }\end{array}$ & 4 & 7,4 & 49 & 90,7 & 0 & 0 & 54 \\
\hline 8 & $\begin{array}{l}\text { Management } \\
\text { Pendidikan }\end{array}$ & 3 & 1,3 & 18 & 81,8 & 1 & 0 & 22 \\
\hline 9 & $\begin{array}{l}\text { Belajar dan } \\
\text { Pembelajaran }\end{array}$ & 0 & 0 & 19 & 100 & 0 & 0 & 19 \\
\hline
\end{tabular}

Tabel di atas menunjukkan bahwa kisaran nilai yang diperoleh oleh mahasiswa yang dalam pembelajarannya menggunakan TIK untuk mata kuliah Keagamaan adalah sebagai beikut : prosentase tertinggi dengan nilai A adalah mata kuliah Terori Penyuluhan Agama yaitu sebesar $66 \%$, dan selanjutnya adalah mata kuliah Sejarah Agama Hindu sebesar 24\%. Profesi Kependidikan 13,6 \%. Prosentase terendah nilai A yang diperoleh mahasiswa adalah mata kuliah Belajar dan Pembelajaran, yang hanya $1 \%$.

\section{PEMBAHASAN}

Bila dilihat dari komentar yang diberikan oleh mahasiswa secara umum, 87,3\% mahasiswa mengatakan senang terhadap penggunaan TIK dalam pembelajaran. Hal ini 
menunjukkan bahwa mahasiswa memiliki persepsi positif terhadap penggunaan TIK dalam pembelajaran. Secara lebih spesifik, persepsi mahasiswa terhadap penggunaan TIK dapat dilihat dari alasan berikut, yaitu : (1) menambah pengetahuan dan wawasan mahasiswa tentang teknologi, dengan kata lain tidak gaptek (96\%), (2) pembelajaran menjadi tidak membosankan karena mahasiswa tidak hanya mendengarkan ceramah dosen (100\%). (3) sangat mempermudah pembelajaran karena visualisasi, gambar dan film yang dipergunakan dalam presentasi lebih cepat membuat mahasiswa mengerti tentang topic yang diajarkan (99\%), (4) dengan menggunakan blog, mahasiswa bisa berkomunikasi dan berbagi ilmu pengetahuan dengan lebih banyak orang (78\%), (5) Dengan menggunakan TIK mahasiswa dapat download banyak hal, sehingga wawasan yang dimiliki tidak hanya sebatas informasi yang diberikan poleh dosen dan teman (80\%), (6) dengan informasi yang lebih banyak, mahasiswa merasa lebih bisa berkreasi (kreatif) (67\%), (7) penggunaan TIK dapat mempermudah dan mempercepat mencari sumber-sumber referensi untuk tugas (80\%), (8) Penggunaan TIK dalam pembelajaran membuat suasana belajar lebih menyenangkan $(72 \%)$, dsbnya.

Bila dibandingkan dengan ketidaksenangan mahasiswa dengan penggunaan TIK, seperti yang telah disampaikan di atas, alasan yang disampaikan oleh mahasiswa hanya sebatas karena TIK memerlukan biaya yang tinggi (100\%). Namun biaya yang tinggi tersebut dirasakan tidak seberapa bila dibandingkan dengan manfaat yang diperoleh oleh mahasiswa. Selain itu persepsi negative mahasiswa terhadap penggunaan TIK ada pada factor kurangnya bersosialisasi (tatap muka) dengan dosen sebanyak (78\%). Namun hal tersebut terimbangi dari persepsi mereka bahwa pembelajaran dengan TIK membuat mahasiswa lebih nyaman mengemukakan pendapat dengan dosen krn mengurangi rasa takut dan canggung (90\%).

Untuk membuktikan persepsi yang diberikan oleh mahasiswa tersebut memang positif terhadap penggunaan TIK dalam pembelajaran digunakanlah questioner yang dapat member informasi tentang hasil yang diperoleh oleh mahasiswa pada mata kuliah keamaan dan mata kuliah kependidikan.

Hasil penelitian menunjukkan bahwa penggunaan TIK memberi kontribusi sebesar 77,7 \% untuk mata kuliah keagamaan terutama mata kuliah Sejarah Agama Hindu dan Theory Penyuluhan Agama. Sedangkan untuk mata kuliah kependidikan sebesar $83 \%$. Besarnya kontribusi penggunaan TIK tersebut menunjukkan bahwa pembelajaran dengan TIK 
memang berkontribusi baik terhadap peningkatan kemampuan mahasiswa untuk mata kuliah keagamaan dan kependidikan.

Meskipun pembelajaran dengan TIK disenangi oleh mahasiswa dan dapat meningkatkan kemampuan mahasiswa dalam mata kuliah keagamaan dan kependidikan hasil penelitian menunjukkan bahwa mahasiswa yang senang diajar hanya dengan TIK hanya (21\%), dan sebagian besar mahasiswa (59\%) lebih senang diajar dengan menggunakan gabungan antara TIK, ceramah dan observasi langsung. Fenomena tersebut menunjukkan bahwa penggunaan TIK secara penuh, tidak terlalu disenangi oleh mahasiswa meskipun banyak manfaat yang diperoleh dan mahasiswa mengatakan sangat senang bila pembelajaran dilakukan dengan menggunakan TIK. Oleh karena itu, dosen sebaiknya tidak mengajar dengan hanya menggunakan TIK dan juga hanya dengan ceramah.

Sehubungan dengan kualitas hasil belajar, pembelajaran yang menggunakan TIK menunjukkan

bahwa : prosentase tertinggi dengan nilai A adalah mata kuliah Sejarah agama Hindu yaitu sebesar $66 \%$, dan selanjutnya adalah mata kuliah Thoery Penyuluhan Agama sebesar $24 \%$. Profesi Kependidikan 13,6 \%.. Hasil interviu mengatakan bahwa pembelajaran dengan metode seperti di atas tidak ada bedanya dengan metode ceramah, apalagi bila dosen hanya membuat power point tanpa berisi selingan gambar, maksudnya hanya kumpulan kalimatkalimat saja. Metode pembelajaran seperti itu tidak memotivasi mahasiswa untuk belajar karena mahasiswa hanya dilibatkan untuk mendengarkan ceramah dosen. Lebih-lebih bila waktu perkuliahan diberikan jam EF (11.30), GH (13.30). Mahasiswa mengantuk, dan materi yang disampiakan dosen cepat lupa.

\section{SIMPULAN}

Berdasarkan hasil dan pembahasan yang dikemukakan dapat disimpulkan hal-hal sebagai berikut : Persepsi mahasiswa terhadap penggunaan TIK dalam pembelajaran adalah positif, terbukti 87,3 \% mahasiswa mengatakan senang dengan pembelajaran dengan TIK. Namun bila dilihat dari persepsi mahasiswa terhadap metode pembelajaran yang menyatakan bahwa $48 \%$ mahasiswa mengatakan bahwa metode pembelajaran yang paling disenangi adalah gabungan antara penggunaan TIK, ceramah dan observasi langsung, serta $43 \%$ mahasiswa yang senang dengan pembelajaran yang hanya menggunakan dalam TIK, dapat disarankan hal-hal sebagai berikut : (a) dosen di jurusan pendidikan agama hindu dihararapkan tidak hanya menggunakan TIK dalam pembelajarannya, akan tetapi agar mengkombinasikannya dengan metode lainnya, 
sehingga manfaat yang diperoleh dari TIK dapat dinikmati oleh mahasiswa dan dampak negatif dari pengggunaan TIK dalam pembelajaran dapat diminimalkan, (b) meski banyak dampak positif yang ditimbulkan dari pembelajaran yang menggunakan TIK, namun dosen diharapkan setiap saat mengingatkan mahasiswa untuk memanfaatkan TIK dengan sebaikbaiknya karena TIK juga bisa menjadi boomerang bagi keberhasilan mahasiswa, (c) dengan banyaknya manfaat yang diperoleh oleh mahasiswa baik kepada diri mereka secara pribadi, proses pembelajaran di jurusan pendidikan agama hindu dan hasil belajar mahasiswa, sebaiknya STKIP Agama Hindu mengusahakan adanya internet gratis.

\section{Daftar Rujukan}

Dryden, Gordon; dan Voss, Jeanette; (1999), "The Learning Revolution: to Change the Way the World Learn", the Learning Web, Torrence, USA, http://www.thelearningweb.net.

Fryer, Wesley A.; (2001), "Strategy for effective Elementary Technology Integration", http://www.wtvi.com/teks/integrate/tcea2001/powerpointoutline.pdf

Yusufhadi Miarso; (2004). "Menyemai Benih Teknologi Pendidikan" Prenada Media, Jakarta.NIE, Singapore, "General Typology of Teaching Strategies in Integrated Learning System”, http://www.microlessons.com.

Norton, Priscilla; dan Spargue, Debra; (2001), "Technology for Teaching”, Allyn and Bacon, Boston, USA.

Susan Stainback. (1988). Understanding and Conducting Qualitative Research. Kendall/Hunt Publishing Company; Dubuque, IOWA

UNESCO Institute for Information Technologies in Education (2002), “Toward Policies for Integrating ICTs into Education" High-Level Seminar for Decision Makers and Policy-Makers, Moscow 2002.

http://www.informatika.lipi.go.id/sistem-pendukung-e-learning-di-web http://www.tempointeraktif.com/hg/it/2006/07/12/brk,20060712-80049,id.html http://www.duniaguru.com/index.php?option=com content\&task=view\&id=344\&ltemid=26 http://www.fe.ui.ac.id/elearning/ http://www.unhas.ac.id/tekpert/claroline181/ http://saifuladi.wordpress.com/2007/01/15/komputer-adalah-media-belajar-anak/ 
Jurnal Widya Sastra Pendidikan Agama Hindu

Volume 3 Nomor 1 Tahun 2020

ISSN: 2656-7466

http://elearning.uny.ac.id/

http://romisatriawahono.net/2006/03/24/teknik-mengadopsi-ccna-ke-kurikulum-pendidikan-formal/

http://www.wahanakom.com/infotek/elearning.htm

http://www.ilmukomputer.com/2006/09/25/bagaimana-mahasiswa-ilmu-komputer-belajar-mengkritisikurikulum-dan-gaya-pendidikan-kital 